\title{
Measuring the Impact of Corporate Social Responsibility Practices on Competitive Advantage: A Mediation Role of Reputation and Customer Satisfaction
}

\author{
Wael Hassan El-Garaihy ${ }^{1}$, Abdel-Kader Mohamed Mobarak ${ }^{2} \&$ Sami Abdullah Albahussain $^{3}$ \\ ${ }^{1}$ Head, Department of Business Administration, College of Applied Studies and Community Service, University \\ of Dammam, Saudi Arabia \& Seconded by University of Port Said, Egypt \\ ${ }^{2}$ Professor, Head of Marketing Department, College of Applied Studies and Community Service, University of \\ Dammam, Saudi Arabia \\ ${ }^{3}$ Associate Professor of Business Administration, Head of Department of Business Administration, College of \\ Business Administration, University of Dammam, Saudi Arabia \\ Correspondence: Wael Hassan El-garaihy, University of Dammam, Saudi Arabia. Tel: 966-568-275-441. E-mail: \\ whgaraihy@ud.edu.sa; wgaraihy@hotmail.com
}

Received: February 23, 2014

Accepted: April 8, $2014 \quad$ Online Published: April 18, 2014

doi:10.5539/ijbm.v9n5p109

URL: http://dx.doi.org/10.5539/ijbm.v9n5p109

This Research Funded by The deanship of Scientific Research, University of Dammam, Saudi Arabia.

\begin{abstract}
Corporates are facing increasing pressure to operate in a socially responsible ways. The importance of Corporate Social Responsibility initiatives is due to their relation to competitive advantage, financial result, customer behavior, and corporate reputation as well. Therefore, the purpose of this study is to examine the mediating role of consumer satisfaction and corporate reputation on achieving competitive advantage for corporates, and then measuring the impact on creating competitive advantage for corporates that apply social responsibility in the Kingdom of Saudi Arabia. The experimental results of the study have demonstrated that the initiatives of (CSR) are affected by the economic, legal, ethical, and discretionary activities. The tests have also confirmed the direct relationship between the initiatives of (CSR) and competitive advantage as a strong positive relationship. The results of this study emphasize on the ability of customer satisfaction and corporate reputation to play completely mediating role between (CSR) and competitive advantage. Customer satisfaction also affects more strongly the achievement of competitive advantage. It affects with direct and indirect relationship through corporate reputation. This has been concluded based on the results from a sample of 300 Saudi corporates. The results of this study indicate that (CSR) appears as an effective strategic objective. Therefore, Saudi corporates should consider the initiatives of (CSR) as a way to construct intangible assets such as customer satisfaction and corporate reputation. Saudi corporates, therefore, need to exert all their efforts to engage in the activities of corporate social responsibility, which represent a powerful strategy for those corporates.
\end{abstract}

Keywords: corporate social responsibility, Saudi corporate, competitive advantage, reputation, customer satisfaction, SEM, conceptual framework

\section{Introduction}

Large corporates are significantly investing in the initiatives of (CSR) (Luo \& Bhattacharya, 2006). The willingness to invest in (CSR) emphasizes that it is not a cost, restriction, or just the right thing which should be done, but it is a source of competitive advantage (Porter \& Kramer, 2006). Not only does the effective use of social responsibility conducted by corporates distinguish the corporate from its competitors, but it also helps corporates to gain a competitive advantage over its competitors (Porter \& Kramer 2006; Smith, 2003).

There are many studies that have experimentally confirmed the relationship between (CSR) and corporate reputation (Brickley, Smith, \& Zimmerman, 2002; Lai, Chiu, Yang, \& Pai, 2010). However, the only method by which the initiatives of (CSR) affecting these results is still not clear. The customer satisfaction is the evaluation of the emotional responses regarding the pleasure gained by the customer from the consumption of goods or services (Petrick, 2002). Luo and Bhattacharya (2006) confirmed that (CSR) has a direct impact of on customer 
satisfaction. On the other hand, the competitive advantage, according to Lamb (2004), is a set of corporate unique features. Its products are also considered by the clients of the targeted market as unique products and superior to competitors' products. This is the factor or factors that support consumers' demand for the corporate products. Most corporates today rely on various strategies to outperform their competitors, such as product quality strategy, cost leadership strategy, differentiation strategy, and provide quality service to customers etc.

The organization achieves a competitive advantage when a corporate acquires or develops a feature or a set of features that enables it to outperform its competitors (Stutz \& Warf, 2009). These qualities or features can include an access to natural resources such as high-quality materials, inexpensive force, or access to highly trained human resources. According to Powell (2001), the business strategy is a tool that deal with resources and contribute to the creation of competitive advantage. Therefore, the applicable business strategy may be inadequate unless it has the control over its unique resources along with the ability to create a unique feature. In summary, the competitive advantage is one of the main determinants of superior performance. It is also struggling to ensure occupying a senior position in the market. The superior performance is the ultimate objective required from the corporate. Therefore, the competitive advantage is the foundation for achieving this performance.

The key research questions of our study are (1) Does the application of (CSR) contribute to the level of customer satisfaction and corporate reputation? (2) Do customer satisfaction and corporate reputation play the mediating role between the practices of social responsibility on one hand and the achievement of competitive advantage for Saudi corporates under study on the other hand?

\section{The Conceptual Framework and Hypotheses Formulation}

The research model is shown in Figure 1. The relevant hypotheses of the model are presented below.

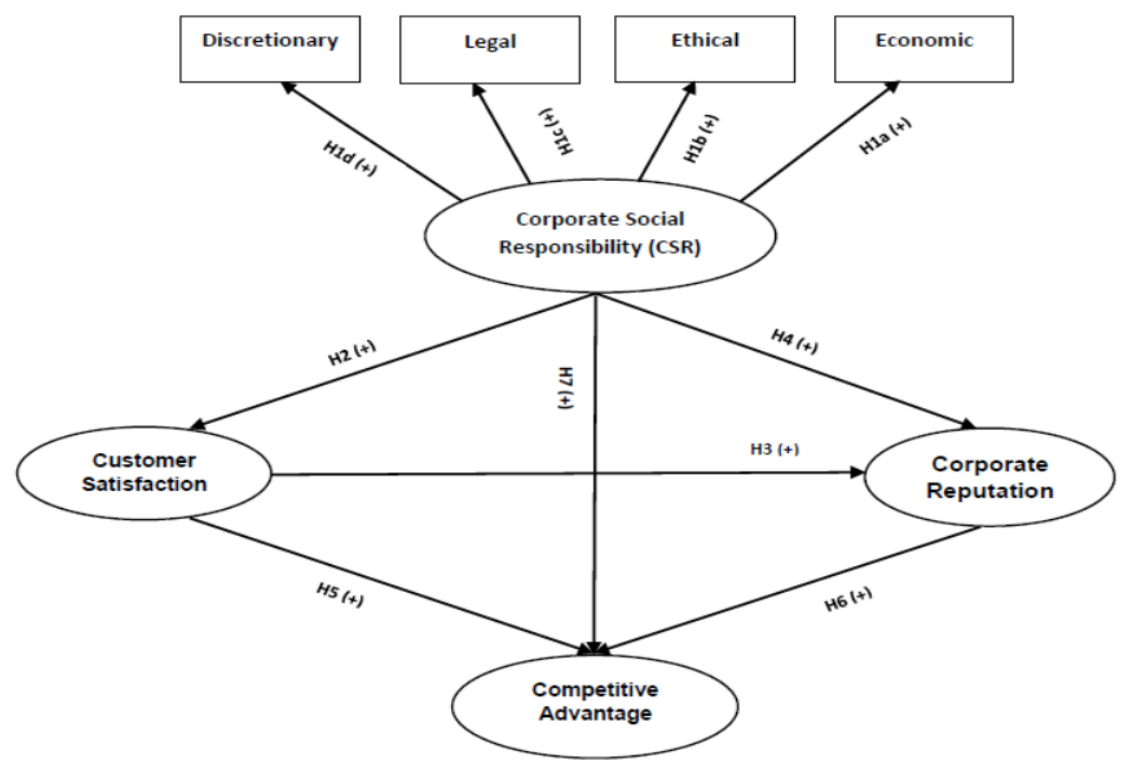

Figure 1. The research model

\subsection{Corporate Social Responsibility}

Investment in the initiatives of (CSR) is considered as a source of competitive advantage and as a tool to enhance financial performance (Smith, 2003; Porter \& Kramer, 2006). Nevertheless, it is not clear whether initiatives of (CSR) can actually be used as a tool to achieve competitive advantage. Viewpoints have been varied since the sixties of last century about whether the financial results provide an evidence of a correlation between (CSR) and competitive advantage (Cochran \& Wood, 1984).

There is a major difference between the initiatives of (CSR) and the features of other traditional marketing mix (e.g. promotion). This difference lies in corporate, consumers, and social issues, representing all benefits that can be achieved from the initiatives of (CSR) (Bhattacharya \& Sen, 2004). This explains why socially 
responsible organization's behavior has a positive effect on consumer behaviors towards the corporate (Lichtenstein, Drumwright, \& Braig, 2004). This positive relationship is supported by through modern theories and empirical evidences. For the same reason, the impact of CSR on the behavior of internal consumer, for example, awareness, is much more significant than its impact on the behavior of external consumer, for example, purchasing behavior, (Bhattacharya \& Sen, 2004).

Corporate Social Responsibility indicates that corporate commits to the community or to those who are affected by its policies and social practices (Smith, 2003; Matten \& Moon, 2004). There are three basic lines to deal with the approaches of (CSR) as the following: Stakeholder-oriented approach, performance-oriented approach, and motives-oriented approach (Basu \& Palazzo 2008). Each approach leads to a unique interpretation of CSR, for example: Stakeholder-oriented approach identifies and measures (CSR) and its role in satisfying the needs of shareholders and external stakeholders (McWilliams, Siegel, \& Wright, 2006). Performance-based approach illustrates the activities and focuses on the relationship among corporate social responsibility, corporate strategy, and required performance (McWilliams et al., 2006). Eventually, motives-based approach reveals the results; it examines the external causes for the correlation of organizations with (CSR) or significant justifications for enhancing the core concepts of the obligations and responsibilities (Basu \& Palazzo, 2008).

Although (CSR) can be visualized in several methods, the structure of social responsibility is a multi-aspect construction (Rowley \& Berman, 2000). One of the most patterns mentioned in literature is that one developed by Carroll (1979). It distinguishes between economy-based responsibilities (satisfying consumers' needs, providing jobs, decent wages, and generate capital for investments), legal aspects (compliance with laws and regulations), ethical aspects (the adoption of justified codes for ethical behavior, and the distinction between right/wrong) or discretionary aspects (actively contribute to the well-being of the community through investing in education and charitable work or help the most vulnerable members of society). Based on these theoretical perspectives, we hypothesize the following:

(H1a): Corporate economic activities would positively affect building corporate social responsibility.

(H1b): Corporate ethical activities would positively affect building corporate social responsibility.

(H1c): Corporate legal activities would positively affect building corporate social responsibility.

(H1d): Corporate discretionary activities would affect building corporate social responsibility.

\subsection{Customer Satisfaction}

Customer satisfaction considers as an introduction of important behavioral results to customers, which are: Customer loyalty, and customer commitment (Donio, Massari, \& Passinate, 2006), repurchase intentions (Elgaraihy, 2013), and positive transfused speech (Cronin, Brady, \& Hult, 2000; Brady \& Robertson, 2001). Based on what indicated by Bagozzi's, 1992, the customers' perceptions lead to their satisfaction. Customer satisfaction leads to promote behavioral intentions of customers in order to maintain these levels of satisfaction they have. Hunt (1977) described customer satisfaction as a process of feelings' evaluation. Based on what indicated by Sweeney, Soutar, \& Johnson (2001), Petrick (2002) defined emotional reaction as "descriptive judgment relating to pleasure that a product or service gives to the buyer". This means that customer satisfaction can be measured by determining to what extent the consumer believes that the generated positive feelings have resulted from the consumption of a product or service (Rust \& Oliver, 1994). In other words, customer satisfaction is considered as a construction, consisting of the customers' evaluative and emotional response toward an organization (Oliver, 1997).

There are three tendencies to illustrate the impact of (CSR) on customer satisfaction (Luo \& Bhattacharya, 2006). (1) The first tendency indicates that the perceived value has a positive impact on customer satisfaction (Athanassopoulos, 2000). (2) Based on theories of social identity and organizational identity, the initiatives of (CSR) lead to high levels of consumer identity - the corporate identity (Bhattacharya \& Sen, 2003), which in turn helps to satisfy the needs of its customers (Luo \& Bhattacharya, 2006). (3) Corporates need to adopt a balanced viewpoint to the interests of all stakeholders and concerned parties to address their demands (Maignan, Ferrell, \& Linda, 2005). Based on these theoretical perspectives, we hypothesize the following:

(H2): The initiatives of (CSR) would have a positive effect on the level of customer satisfaction.

Bontis, Booker, and Serenko (2007) indicated that the relationship between customer satisfaction and corporate reputation did not receive due attention. Anderson and Sullivan (1993) conclude that a high level of satisfaction leads to a good reputation for the corporate in the long term. According to the results concluded by Bontis et al. (2007), customer satisfaction has a positive impact on corporate reputation, customer loyalty, and recommendation to deal with the corporate. In other words, the route from customer satisfaction to corporate 
reputation has been confirmed by many of the studies' results. We, therefore, hypothesize that corporates which have been positively recognized by consumers regarding the initiatives of corporate social responsibility; would have higher levels of customer satisfaction, which in turn make consumers have more positive perceptions regarding corporate reputation. Based on these theoretical perspectives, we hypothesize the following:

(H3): The level of customer satisfaction would have a positive impact on corporate reputation.

\subsection{Corporate Reputation}

Corporate reputation is considered as aggregate provisions about the corporate based on the evaluation of the effects of financial, social, and environmental aspects of the corporate over a period of time (Barnett, Jermier, \& Lafferty, 2006). This reputation is one of the intangible assets about which marketing and financial performance is concerned (Schwaiger, 2004; Miles \& Covin, 2000). Miles and Covin (2000) suggested that corporate reputation is an indicator of the corporate credibility, trust, reliability and responsibility. Corporates that produce high-quality products, use the right publicity, do businesses concerned about social and environmental responsibility, and fulfill their obligations toward stakeholders can create the advantage of good reputation (Miles \& Covin, 2000). Competitive advantage based on corporate reputation is one of the intangible assets, which is a source of strategic advantage that enhances the ability of corporates to create a value over the long term (Caves \& Porter, 1977).

McWilliams et al. (2006) indicated that (CSR) is a form of strategic investment, which can be considered a form of building or maintaining reputation. On the other hand, Fombrun (2005) suggested that corporate reputation can be enhanced as an incentive to engage in the activities of corporate social responsibility. Garberg and Fombrun (2006) also drew the attention that the gains of corporate reputation are of the results related to the programs of corporate social responsibility consequently, we hypothesize the following:

(H4): The initiatives of (CSR) would have a positive effect on the level of corporate reputation.

\subsection{The Mediating Effects of Customer Satisfaction and Corporate Reputation between CSR and Competitive Advantage}

There are many attempts to interpret the relationship between the social responsibility and competitive advantage. In spite of the obvious positive results of those attempts, they provided a partial perception of the whole picture of that relationship (Saeed \& Arshad, 2012). This would suggest that scientists have tried to develop this concept more than any other time to examine the relationship between (CSR) and competitive advantage. That has led to a more accurate assessment of the variables that link between (CSR) and competitive advantage. Customer satisfaction and company reputation are two of these variables. The results of many studies indicate that corporate social responsibility, reputation, and customer satisfaction have positive effects on the competitive advantage. Therefore, the underlying reason for the positive relationship between (CSR) and competitive advantage is due to the effects of corporate reputation and customer satisfaction. These results are due to the following reasons:

(1) The (CSR) indicates that corporates need to demonstrate the societal benefits. Society needs to recognize that these benefits are of value to the corporate so that it can be viewed as socially responsible. One of the methods that consider the benefits of measures of social responsibility by the community is through the value of positive reputation (Brammer \& Pavelin, 2004). Spence (2002) suggested that CSR has a positive impact on the reputation. This arises from the fact that the corporate offers behavioral evidence, emphasizing that it is socially responsible. The decision of the stakeholders about that corporate are positively affected, which is regarded as the basis of reputation (Fombrun \& Shanley, 1990). If corporate reputation is considered as the representation of public opinion, these views rely on satisfying the expectations of stakeholders, and having the ability to demonstrate a high level of corporate social responsibility, which indicates that the corporate will act according to the expectations of stakeholders (Brammer \& Pavelin, 2006).

(2) There is a positive relationship between customer satisfaction and corporate reputation (Walsh, Mitchell, Jackson, \& Beatty, 2009; Wang, Lo, H-P., \& Hui, 2003). The major reason for this relationship is that a reputation is essentially a result of the previous transactions that demonstrate to stakeholders the extent of interest in the corporate to efficiently meet its obligations, and it is also consistent with their expectations (Brown \& Logsdon, 1999). In this way, if reputation is efficiently developed, it will become one of the most important strategic resources of the corporate (Flanagan \& O'Shaughnessy, 2005).

The third pattern of literature, enabling us to connect (CSR) with customer satisfaction is studying introductions of customer satisfaction. For example, the perceived value is a major introduction, which is experimentally proved it enhances customer satisfaction (Mithas, Krishnan, \& Fornell, 2005). Moreover, the involvement in 
CSR may allow corporates to better understand their customers, and thus to improve the specific knowledge among their customers (Sen \& Bhattacharya, 2001). Improving customer knowledge represents other introduction to enhance customer satisfaction (Jayachandran, Sharma, \& Pushkala, 2005; Mithas et al., 2005). Based on the foregoing, we hypothesize the following:

(H5): Customer satisfaction would positively impact competitive advantage of corporates when it acts as mediating role between (CSR) and competitive advantage.

(H6): Corporate reputation would positively affect competitive advantage of corporates when they play the mediating role between (CSR) and competitive advantage.

\subsection{Competitive Advantage}

Competitive advantage is a complex subject, covering various issues, with a focus on competitive tools such as quality, speed, innovation, leadership, and various other factors that are important in the industrial and service sectors. The development of competitive strategy is vital to the survival and prosperity of any organizations, to play a significant role in their industry. Before the corporate can build a sustainable competitive advantage, it has to work on the formulation of a competitive strategy. The competitive strategy is defined as taking the offensive or defensive actions to create a defensive position in the industry or to deal successfully with competitive forces, and thus generate a higher return on investment for the corporate (Kotler \& Keller, 2006). Competitive advantage can be constructed through seeking to achieve competitive strategies such as corporate social responsibility, and customers' strategies such as customer relationship management, and provide excellent service, high quality, cost leadership, and differentiation.

Marketing literature has presented rare attempts to the relationship between CSR and competitiveness, although that relationship has dramatically developed in the past few years. Most studies have focused on the relationship between competitive ability and (CSR) in an attempt to prove that there is a positive relationship between CSR and financial performance (McWilliams \& Siegel, 2001). Due to the inconclusive results (Chand \& Fraser, 2006), some of the other authors have suggested alternative approaches, such as the generation of corporate competitive advantage by creating value for the stakeholders (Freeman, 1984), and the evaluation of (CSR) as a risk to the main competitive variables such as reputation and the mental image (Schnietz \& Epstein, 2005; Carlisle \& Faulkner, 2005), or using case studies (Juholin, 2004; Gueterbok, 2004). The bottom line here is that it seems to be a relationship between CSR and competitive ability; however, the nature of the relationship is unclear. Moreover, the financial performance or the corporate value may not automatically mean competitive ability over the long term (Porter \& Kramer, 2006; McWilliams \& Siegel, 2001).

What is important now, is that many of the above-mentioned issues are considered intangible assets that are neither measured nor traditionally formed, and certainly did not explicitly inserted among the five forces in Porter's Model of competitive advantage (Porter, 1985). Therefore, some of the key determinants of corporate competitive advantage are concentrated in some of matters such as brand, reputation and innovation, for example but not inclusively. These issues strongly influenced by corporate social responsibility. The bottom line is the hypothesized following:

(H7): (CSR) Initiatives would have a positive impact on competitive advantage.

\section{Research Methods}

\subsection{Sample Selection and Data Collection Procedure}

The study has been based on a survey of industrial corporates in Saudi Arabia. The sample included 300 corporates from a wide range of industries, including petroleum, chemical, machinery and equipment, automotive, electronics, computer, steel and metals, food, agriculture. E-mail survey has been used to collect data in the study. 15 Pilot tests have been conducted with marketing managers and executives who are the representatives of the research sample. The initial test aims at the revised questionnaire to assess its validity and relevance of measuring the purpose it assigned for. Adjustments have been made to the questionnaire after conducting experimental tests. Questionnaires have been sent to the marketing managers. The number of retrieved questionnaires was 280 , including 205 useable questionnaires. That means, the effective response rate is almost $68.3 \%$. According to Aaker, Kumar, and Day, (2001), the response rate of the survey mail is acceptable if it is more than $20 \%$. To assess the possibility of non-response bias, it has been tested by statistical t-test. 205 is the number of questionnaires applied for analysis in this research. From 205 questionnaires which represent the sample, there were 92 questionnaires, representing $44.9 \%$ of the sample for the companies that have an experience in the initiatives of (CSR) ranging from 1-3 years. 113 questionnaires, representing $55.1 \%$, indicated that their experience in the initiatives of (CSR) has been more than three years. The results indicate that 
participants have sufficient knowledge of the initiatives of corporate social responsibility. $(70 \%)$ of the sample ages ranged between 45-60 years, while (30\%) of the ages ranged between 27 and 44 years. The participants having high levels of education represented about $72 \%$.The results illustrated that non-response bias is not a significant problem in our available data.

\subsection{Measures}

The questionnaire contained five sections. The first section has been allocated to get the perceptions of respondents to the initiatives of (CSR) under study. The second Section of the questionnaire has been allocated to identify the perceptions of respondents about satisfaction. The third section has been allocated to measure respondents' perceptions about corporate reputation. The fourth section has been allocated to measure perceptions related to the measurement of competitive advantage. The responses to the items of these four sections have been according to Fifth Likert Scale, so that (1) = Strongly Disagree and (5) = Strongly Agree. Demographic questions have been included in Section VI. To improve the ability of respondents to understand the questionnaire questions and the possibility of reading correctly, the questionnaire has been tested and revised before being presented to the respondents, through the presentation to the two groups of specialists, the first one included some specialists in the field of (CSR) in the Kingdom. The second group included some of marketing and business administration professors at the University of Dammam.

\subsection{Independent Variable}

After many studies have been reviewed to reach a suitable scale for measuring corporate social responsibility, it has been concluded that the scale used in the studies (Galbreath \& Shum, 2012; Maignan \& Ferrell, 2000), is the most suitable to the subject of our research for the following reasons: Through this, various activities of social responsibility have been determined and developed. They are consistent with the perception of Carroll (1979) of corporate social responsibility. Thus, it is the concept that we rely upon in this study. The scale assesses the aspects of the various activities of corporate social responsibility, which indicates that the scale is suitable for our study. The scale consists of four aspects (Economic, ethical, legal and discretionary activities), including 29 elements to measure the activities of corporate social responsibility. Development processes have been conducted on the scale in many of the previous studies.

\subsection{Intermediate Variables}

For measuring reputation, this study has relied on reputation scale that conducted by Weiss, Anderson, \& MacInnis (1999). They have developed an evaluation the common perception of corporate reputation. The scale does not evaluate the reputation for specific thing, such as (product innovation), but that measure was asking participants to determine the extent of their awareness of their corporate reputation in general. The measure consists of six key elements to measure corporate reputation.

The customer satisfaction indicators should include the ability to conduct a comprehensive evaluation of customer transactions with the corporate. Therefore, and in line with what concluded by Ping (1993) four items relating to the customers' expectations and the relationship between the customer and the corporate have been relied on. In addition, the four items commonly used in various researches to measure customer satisfaction indicators for the construction of satisfaction have been relied on (Oliver \& Swan, 1989). Consequently, the measure of customer satisfaction included eight elements designed to measure the perceptions of customer satisfaction levels.

\subsection{Dependent Variable}

There is a broad acceptance, considering time to the market as a source of competitive advantage (Holweg, 2005). Many studies considered that price/cost, quality, and delivery dependability, and time to market are of the significant competitive abilities (Vokurka, Zank, \& Lund, 2002; Tracey, Vonderembse, \& Lim, 1999). In the framework of the research conducted by Koufteros, Vonderembse, \& Doll (1997), the following five aspects of competitive abilities have been adopted: competitive prices, excellent pricing, and quality for customers' value, delivery dependability, and product innovation. These aspects were reliable and utilized in many other researches, such as (Lai et al., 2006; Koufteros et al., 2002; Tracey et al., 1999). Based on what is stated in these studies, our research relied on five aspects of competitive advantage, which are Price/cost, quality, delivery dependability, product innovation, and time to market. Accordingly, the measure of competitive advantage includes 14 elements designed to measure the competitive advantage. 


\section{Procedures (Data Analysis and Results)}

\subsection{Factor Analysis and Scale Reliabilities}

Confirmatory factor analysis (CFA) has been conducted, using (AMOS. 16) to test the standardized validity of the measure used in the study. Byrne (2001) recommended using confirmatory factor analysis through exploratory factor analysis, because of its theoretical basis to explain the measure errors; as well as, to test uni-dimensional model. To reach the last set of items for each construct, 12 items representing the first group have been canceled of 61 . This was based on item-total correlations, and the standardized remaining values. That procedure was taken on the basis of what concluded by (Byrne, 2001). The eliminated items were tested and assimilated to original conceptual definitions of the constructs. In each case, factors having any significant changes on the construction field associated with them have not been eliminated. As it was conceived primarily, remaining factors were subjected to confirmatory factor analysis. Completely standardized solution resulted from Amos 16, using the maximum probability estimation resulted in that all 42 remaining items burdened extremely on their analogous factors, which confirmed the uni-dimensionality of the constructs. They also supplied effective experimental proof of their validity. Also $t$-values of burdens were high, which indicates sufficient convergent validity. The results of the measure model are as follows: $\left(\mathrm{X}^{2} 205=171.392 ; \mathrm{p}=0.000\right.$; $(\mathrm{GFI})=0.90 ;(\mathrm{AGFI})=0.85 ;(\mathrm{CFI})=0.94 ;(\mathrm{IFI})=0.95 ;(\mathrm{RMSEA})=0.07)$.

This indicates a positive adaptation. Table I below indicates both the measure model and the standardized burdens; in addition to the critical ratios (Byrne, 2001; Hair, Jr., Anderson, Tatham, \& Black, 1998). Cronbach alpha coefficients have been calculated to determine the level of reliability of the various constructions of the study. It has been 0.88 (corporate social responsibility), 0.85 (Customer satisfaction), 0.94 (Corporate reputation), and 0.81 (Competitive advantage). Thus, the credibility has ranged between 0.81-0.94, which provided more support to make sure that all measures used in this research have acceptability and reliability (Nunnally, 1978). Table 2 indicates the internal correlation, median, and the standard deviations of the constructs used in the research.

Table 1. The measurement model

\begin{tabular}{|c|c|c|c|c|c|}
\hline \multicolumn{2}{|c|}{ Constructs } & SCR & VE & SL & (CR) \\
\hline \multicolumn{6}{|c|}{ Corporate social responsibility (CSR) } \\
\hline \multicolumn{6}{|c|}{ Economic Aspect (EA): } \\
\hline & & 0.87 & 0.73 & & \\
\hline EA1 & Our business employs each process to reply every customer dissatisfaction. & & & 0.89 & 15.56 \\
\hline EA2 & Our products' quality is successively enhanced. & & & 0.87 & 14.37 \\
\hline EA3 & Customer satisfaction is utilized as an indicator of our business performance. & & & 0.85 & 14.01 \\
\hline EA4 & Our profits have been successfully maximized. & & & 0.82 & 12.91 \\
\hline EA5 & Great efforts are exerted to lower our operating costs. & & & 0.81 & Fixed \\
\hline \multicolumn{6}{|c|}{ Legal Aspect (LA): } \\
\hline & & 0.85 & 0.72 & & \\
\hline LA1 & Directors are instructed about applicable environmental laws. & & & 0.91 & 13.12 \\
\hline LA2 & All our products satisfy legal standards. & & & 0.87 & 13.06 \\
\hline LA3 & Our contractual agreements are always respected. & & & 0.85 & 12.54 \\
\hline LA5 & Our corporate strives to consent to all laws concerning hiring and employee benefits. & & & 0.83 & 11.79 \\
\hline LA7 & $\begin{array}{l}\text { Non-discrimination among employees in compensation and promotion is supported by } \\
\text { internal procedures. }\end{array}$ & & & 0.80 & Fixed \\
\hline
\end{tabular}

Ethical Aspect (ETA):

ETA1 Our business has an inclusive code of conduct. $0.91 \quad 0.84$

ETA2 Our staffs are obliged with professional standards.

$0.92 \quad 21.81$

ETA3 Senior managers supervise the possible negative effects of our activities on our society.

ETA5 Justice toward coworkers and business partners is an essential section of our staff assessment procedure.

ETA6 All our customers are provided with full and precise information by sales assistants and staffs. 


\section{Discretionary Aspect (DYA):}

\begin{tabular}{|c|c|c|c|c|c|}
\hline & & 0.82 & 0.71 & & \\
\hline DYA1 & Our firm offers more competitive salaries than any other industry. & & & 0.86 & 13.91 \\
\hline DYA2 & Our staffs are encouraged to join civil society that supports our community. & & & 0.83 & 12.76 \\
\hline DYA3 & $\begin{array}{l}\text { Elastic corporate procedures allow staffs to better harmonize profession and personal } \\
\text { life. }\end{array}$ & & & 0.81 & 11.91 \\
\hline DYA4 & We support collaboration with local businesses and schools. & & & 0.78 & 10.76 \\
\hline DYA5 & Local sports and cultural activities are encouraged by our business. & & & 0.84 & Fixed \\
\hline \multicolumn{6}{|c|}{ Corporate Reputation(CR) } \\
\hline & & 0.93 & 0.82 & & \\
\hline CR1 & Customers' comprehensive sense of total experience in the corporate is excellent. & & & 0.89 & 17.56 \\
\hline CR3 & Customers are optimistic about long-term future of this corporate. & & & 0.96 & 19.81 \\
\hline CR4 & The corporate is characterized with honesty. & & & 0.91 & 18.06 \\
\hline CR5 & The corporate is characterized with credibility. & & & 0.88 & 13.47 \\
\hline CR6 & The corporate is characterized with dependability. & & & 0.83 & Fixed \\
\hline
\end{tabular}

\section{Customer Satisfaction(CS)}

CS1 Our products satisfy what the customer requires.

0.86

0.78

CS3 Our products are almost perfect for our customer.

$0.84 \quad 15.44$

CS5

Our Products and services commonly satisfy our customers' expectations.

$\begin{array}{ll}0.92 & 17.69\end{array}$

CS6 Our Products and services are strongly requested by our customers.

$0.87 \quad 15.86$

CS8 Our products and services always make our customers be happy and delighted.

$0.84 \quad 12.32$

Competitive advantage:

Price/ cost (PC):

$\begin{array}{rrr} & 0.68 & 0.62\end{array}$

PC1 Our prices are competitive.

$0.78 \quad$ Fixed

PC2 Our prices are low or lower than those of our competitors.

\section{Quality $(Q L)$ :}

$0.74 \quad 12.71$

$0.81 \quad$ Fixed

QL1 Quality is our weapon for the competition.

$0.83 \quad 0.73$

QL2 Our products are very credible.

$0.79 \quad 13.37$

QL3 Our products are very sturdy.

$0.86 \quad 15.21$

QL4 We provide high quality products to our customers.

$0.81 \quad 14.49$

\section{Delivery Dependability (DD)}

$0.78 \quad$ Fixed

\begin{tabular}{|c|c|c|c|c|c|}
\hline & & 0.86 & 0.76 & & \\
\hline DD1 & Our customer orders are highly considered to deliver on time. & & & 0.77 & 12.81 \\
\hline DD2 & We provide dependable delivery. & & & 0.83 & Fixed \\
\hline \multicolumn{6}{|c|}{ Time to Market (TTM) } \\
\hline & & 0.81 & 0.68 & & \\
\hline TTM1 & We are pioneers in innovating new products. & & & 0.80 & 13.29 \\
\hline TTM2 & We commit ourselves with time-to-market. & & & 0.87 & 16.11 \\
\hline TTM3 & Our product is rapidly developed. & & & 0.83 & Fixed \\
\hline \multicolumn{6}{|c|}{ Product Innovation $(P I)$} \\
\hline & & 0.73 & 0.62 & & \\
\hline PI1 & Our products are customizable. & & & 0.69 & 12.01 \\
\hline PI2 & We modify our products promotions to meet our customers' needs. & & & 0.76 & 12.91 \\
\hline $\mathrm{PI} 3$ & We satisfy customer desires for "new" characteristics. & & & 0.72 & Fixed \\
\hline
\end{tabular}

Note. $\mathrm{SCR}=$ (Scale composite reliability), $\mathrm{VE}=$ (Variance extracted $), \mathrm{SL}=($ Standardized loadings $), \mathrm{CR}=($ Critical ratio). 
Table 2. Construct inter-correlation matrix

\begin{tabular}{|c|c|c|c|c|c|c|c|c|c|c|c|c|}
\hline \multicolumn{2}{|c|}{ Constructs } & $\mathrm{CS}$ & $\mathrm{CR}$ & EA & LA & ETA & DYA & $\mathrm{PC}$ & QL & $\mathrm{DD}$ & TTM & PI \\
\hline $\begin{array}{l}\text { Customer } \\
\text { (CS) }\end{array}$ & Satisfaction & 1 & & & & & & & & & & \\
\hline $\begin{array}{l}\text { Corporate } \\
\text { (CR) }\end{array}$ & Reputation & 0.727 & 1 & & & & & & & & & \\
\hline Economic As & spect (EA) & 0.512 & 0.765 & 1 & & & & & & & & \\
\hline Legal Aspect & (LA) & 0.466 & 0.370 & 0.769 & 1 & & & & & & & \\
\hline Ethical Aspe & ect (ETA) & 0.487 & 0.712 & 0.575 & 0.770 & 1 & & & & & & \\
\hline $\begin{array}{l}\text { Discretionary } \\
\text { (DYA) }\end{array}$ & y & 0.268 & 0.354 & 0.319 & 0.404 & 0.735 & 1 & & & & & \\
\hline Price/ cost $(\mathrm{P}$ & PC) & 0.329 & 0.301 & 0.475 & 0.403 & 0.437 & 0.841 & 1 & & & & \\
\hline Quality (QL) & & 0.474 & 0.302 & 0.538 & 0.413 & 0.431 & 0.760 & 0.826 & 1 & & & \\
\hline $\begin{array}{l}\text { Delivery } \mathrm{I} \\
\text { (DD) }\end{array}$ & Dependability & 0.295 & 0.403 & 0.301 & 0.419 & 0.460 & 0.601 & 0.539 & 0.869 & 1 & & \\
\hline Time to Marl & rket (TTM) & 0.311 & 0.344 & 0.362 & 0.405 & 0.508 & 0.653 & 0.632 & 0.701 & 0.864 & 1 & \\
\hline Product Inno & ovation (PI) & 0.354 & 0.345 & 0.402 & 0.346 & 0.382 & 0.626 & 0.641 & 0.524 & 0.575 & 0.935 & 1 \\
\hline Mean & & 4.95 & 4.38 & 3.92 & 3.95 & 3.88 & 3.72 & 4.16 & 4.21 & 4.45 & 4.17 & 4.57 \\
\hline Standard dev & viation & 1.31 & 1.43 & 1.49 & 1.42 & 1.47 & 1.38 & 1.22 & 1.51 & 1.47 & 1.63 & 1.26 \\
\hline
\end{tabular}

Note. The inter-correlations, means, and standard deviations of all constructs used in the study are reported in Table 2.

\subsection{Hypothesized Model}

Structural modeling equations have been used to evaluate the parameters of the hypothesized, which identified (CSR) as exogenous constructs. As (CSR) was correlated to mediating constructs, corporate reputation, and customer satisfaction, and also was correlated to constructing competitive advantage. Mediating constructs were also correlated to the competitive advantage. Customer satisfaction was also correlated to corporate reputation. The statistics of model validity conformity showed a comprehensive reliability level of the hypothesized model analysis. All have been accepted as follows: $\mathrm{x}^{2} 205=171.52 ; \mathrm{p}=0.000$; degrees of freedom $=83$; GFI $=0.91$; AGFI $=0.89 ;$ CFI $=0.95$; IFI $=0.96$; RMSEA $=0.07$. Table 3 indicates the results of SEM. According to Anderson and Gerbing (1988), the convergent validity becomes available at the critical ration (CR) of the studied variables versus their corresponding latent variables. If the critical ration is more than 1.96 at the significant level of 0.05 . Table I indicates that the scale composite credibility and the average variance extracted for each construct has been very acceptable. Composite dependability, a measure of internal consistency dependability, has been a further evidence of convergent validity, which was calculated from the solutions of AMOS.16 program. It has ranged between 0.71 and 0.93 . The results confirmed that the average variance extracted has ranged between 0.64 and 0.84 . It is more than the acceptable level with previous studies such as (Hair et al., 1998). It can also be noted, from Table 3, that the critical ratios of the various constructions implications achieve these standards. Therefore, convergent validity of used scales; in addition to the proposed relations among different scales have been confirmed.

As we have hypothesized, (CSR) is composed of four constructs that are the economic activities (parameter estimation $=0.231, t$-value $=4.650$ ), Legal activities (parameter estimation $=0.346, t$-value $=4.257)$, ethical activities (parameter estimation $=0.329, t$-value $=4.423$ ), and finally the discretionary activities (parameter estimation $=0.281, t$-value $=4.501)$. They all have significant and positive relationships. Therefore, the hypotheses H1a, H1b, H1c, and H1d have been approved. As hypothesized, (CSR) had a significant and positive relationship with both customer satisfaction (parameter estimate $=0.533, t$-value $=6.593$ ), corporate reputation (parameter estimation $=0.246, t$-value $=3.438$ ). It had also a positive relationship with the competitive advantage (parameter estimation $=0.552, t$-value $=6.854$ ), so hypotheses $\mathrm{H} 2, \mathrm{H} 3$, and $\mathrm{H} 4$ have been approved. As we hypothesized, customer satisfaction (parameter estimation $=0.415, t$-value $=5.255$ ) and corporate reputation (parameter estimation $=0.461, t$-value $=5.712$ ) had a positive relationship with competitive advantage, therefore, hypotheses H5 and H6 have also been approved. Eventually, there was a strong and positive relationship between the customer satisfaction and corporate reputation (parameter estimation $=0.489$, $t$-value $=6.014)$, therefore, the last hypothesis $\mathrm{H} 7$ has been approved. 
Table 3. Structural model estimates

\begin{tabular}{|c|c|c|c|c|c|}
\hline RELATION & Estimates & $\begin{array}{c}\text { Standard } \\
\text { error }\end{array}$ & $\begin{array}{l}\text { Critical } \\
\text { ratio }\end{array}$ & $\mathrm{P}<$ & $\begin{array}{c}\text { Standardized } \\
\text { estimates }\end{array}$ \\
\hline $\mathrm{CSR} \longrightarrow$ Customer Satisfaction (CS) & 0.463 & 0.068 & 6.694 & 0.000 & 0.544 \\
\hline $\mathrm{CSR} \longrightarrow$ Corporate Reputation $(\mathrm{CR})$ & 0.311 & 0.064 & 3.549 & 0.000 & 0.257 \\
\hline $\mathrm{CSR} \longrightarrow$ Competitive advantage $(\mathrm{CA})$ & 0.575 & 0.081 & 6.845 & 0.000 & 0.563 \\
\hline Customer Satisfaction $\longrightarrow$ Corporate Reputation & 0.596 & 0.086 & 6.911 & 0.000 & 0.548 \\
\hline Customer Satisfaction $\longrightarrow$ Competitive advantage & 0.471 & 0.070 & 5.255 & 0.000 & 0.426 \\
\hline Corporate Reputation $\longrightarrow$ Competitive advantage & 0.277 & 0.062 & 3.190 & 0.000 & 0.248 \\
\hline $\mathrm{CSR} \longrightarrow$ Economic Aspect (EA) & 0.305 & 0.073 & 3.850 & 0.000 & 0.297 \\
\hline $\mathrm{CSR} \longrightarrow$ Legal Aspect (LA) & 0.223 & 0.057 & 3.662 & 0.000 & 0.243 \\
\hline $\mathrm{CSR} \longrightarrow$ Ethical Aspect (ETA) & 0.463 & 0.081 & 6.593 & 0.000 & 0.544 \\
\hline $\mathrm{CSR} \longrightarrow$ Discretionary Aspect (DYA) & 0.234 & 0.063 & 3.438 & 0.000 & 0.257 \\
\hline Competitive advantage $\longrightarrow$ Price/ cost & 0.575 & 0.087 & 6.965 & 0.000 & 0.574 \\
\hline Competitive advantage $\longrightarrow$ Quality & 0.485 & 0.082 & 6.833 & 0.000 & 0.570 \\
\hline Competitive advantage $\longrightarrow$ Delivery Dependability & 0.465 & 0.077 & 5.917 & 0.000 & 0.437 \\
\hline Competitive advantage $\longrightarrow$ Time to Market & 0.279 & 0.063 & 3.301 & 0.000 & 0.258 \\
\hline Competitive advantage $\longrightarrow$ Product Innovation & 0.294 & 0.064 & 3.861 & 0.000 & 0.296 \\
\hline Economic Aspect $(\mathrm{EA}) \longrightarrow$ EA1 & 0.948 & 0.083 & 14.709 & 0.000 & 0.844 \\
\hline Economic Aspect (EA) $\longrightarrow$ EA2 & 0.932 & 0.077 & 14.188 & 0.000 & 0.809 \\
\hline Economic Aspect (EA) $\longrightarrow$ EA3 & 0.928 & 0.077 & 13.869 & 0.000 & 0.801 \\
\hline Economic Aspect $(\mathrm{EA}) \longrightarrow$ EA4 & 0.912 & 0.072 & 13.334 & 0.000 & 0.798 \\
\hline Economic Aspect (EA) $\longrightarrow$ EA5 & 1.000 & & & 0.000 & 0.849 \\
\hline Legal Aspect (LA) $\longrightarrow$ LA1 & 0.883 & 0.084 & 11.479 & 0.000 & 0.833 \\
\hline Legal Aspect (LA) $\longrightarrow$ LA2 & 0.902 & 0.086 & 11.882 & 0.000 & 0.883 \\
\hline Legal Aspect (LA) $\longrightarrow$ LA3 & 0.945 & 0.089 & 12.007 & 0.000 & 0.894 \\
\hline Legal Aspect (LA) $\longrightarrow$ LA5 & 1.048 & 0.091 & 14.993 & 0.000 & 0.917 \\
\hline Legal Aspect $(\mathrm{LA}) \longrightarrow \mathrm{LA} 7$ & 1.000 & & & 0.000 & 0.931 \\
\hline Ethical Aspect (ETA) $\longrightarrow$ ETA1 & 0.986 & 0.094 & 22.733 & 0.000 & 0.920 \\
\hline Ethical Aspect (ETA) $\longrightarrow$ ETA2 & 0.959 & 0.087 & 21.839 & 0.000 & 0.911 \\
\hline Ethical Aspect $(\mathrm{ETA}) \longrightarrow$ ETA3 & 0.911 & 0.081 & 19.844 & 0.000 & 0.901 \\
\hline Ethical Aspect (ETA) $\longrightarrow$ ETA5 & 0.893 & 0.074 & 18.740 & 0.000 & 0.889 \\
\hline Ethical Aspect (ETA) $\longrightarrow$ ETA6 & 1.000 & & & 0.000 & 0.928 \\
\hline Discretionary Aspect (DYA) $\longrightarrow$ DYA1 & 0.778 & 0.069 & 12.765 & 0.000 & 0.802 \\
\hline Discretionary Aspect (DYA) $\longrightarrow$ DYA2 & 0.917 & 0.081 & 13.765 & 0.000 & 0.844 \\
\hline Discretionary Aspect (DYA) $\longrightarrow$ DYA4 & 0.948 & 0.085 & 13.876 & 0.000 & 0.872 \\
\hline Discretionary Aspect (DYA) $\longrightarrow$ DYA7 & 0.963 & 0.089 & 14.015 & 0.000 & 0.894 \\
\hline Discretionary Aspect (DYA) $\longrightarrow$ DYA8 & 1.000 & & & 0.000 & 0.921 \\
\hline Corporate Reputation $(\mathrm{CR}) \longrightarrow \mathrm{CR} 1$ & 0.739 & 0.042 & 19.745 & 0.000 & 0.882 \\
\hline Corporate Reputation $(\mathrm{CR}) \longrightarrow \mathrm{CR} 3$ & 0.752 & 0.049 & 19.767 & 0.000 & 0.889 \\
\hline Corporate Reputation $(\mathrm{CR}) \longrightarrow \mathrm{CR} 4$ & 0.811 & 0.062 & 21.634 & 0.000 & 0.905 \\
\hline Corporate Reputation $(\mathrm{CR}) \longrightarrow$ CR5 & 0.906 & 0.079 & 13.656 & 0.000 & 0.912 \\
\hline Corporate Reputation $(\mathrm{CR}) \longrightarrow \mathrm{CR} 6$ & 1.000 & & & 0.000 & 0.938 \\
\hline Customer Satisfaction $(\mathrm{CS}) \longrightarrow \mathrm{CS} 1$ & 0.817 & 0.084 & 11.449 & 0.000 & 0.812 \\
\hline Customer Satisfaction $(\mathrm{CS}) \longrightarrow \mathrm{CS} 3$ & 0.878 & 0.087 & 11.993 & 0.000 & 0.834 \\
\hline Customer Satisfaction $(\mathrm{CS}) \longrightarrow \mathrm{CS} 5$ & 0.981 & 0.089 & 12.009 & 0.000 & 0.875 \\
\hline Customer Satisfaction $(\mathrm{CS}) \longrightarrow \mathrm{CS} 6$ & 0.997 & 0.092 & 12.993 & 0.000 & 0.903 \\
\hline Customer Satisfaction $(\mathrm{CS}) \longrightarrow \mathrm{CS} 8$ & 1.000 & & & 0.000 & 0.919 \\
\hline Price/ cost $(\mathrm{PC}) \longrightarrow \mathrm{PC} 1$ & 0.923 & 0.064 & 21.844 & 0.000 & 0.811 \\
\hline Price/ cost $(\mathrm{PC}) \longrightarrow \mathrm{PC} 2$ & 1.000 & & & 0.000 & 0.839 \\
\hline Quality $(\mathrm{QL}) \longrightarrow$ QL1 & 0.876 & 0.074 & 19.871 & 0.000 & 0.837 \\
\hline Quality $(\mathrm{QL}) \longrightarrow$ QL2 & 0.892 & 0.079 & 21.340 & 0.000 & 0.876 \\
\hline Quality $(\mathrm{QL}) \longrightarrow$ QL3 & 0.938 & 0.083 & 21.876 & 0.000 & 0.901 \\
\hline Quality $(\mathrm{QL}) \longrightarrow$ QL4 & 1.000 & & & 0.000 & 0.921 \\
\hline Delivery Dependability (DD) $\longrightarrow$ DD1 & 0.917 & 0.074 & 15.765 & 0.000 & 0.694 \\
\hline Delivery Dependability (DD) $\longrightarrow$ DD2 & 1.000 & & & 0.000 & 0.813 \\
\hline
\end{tabular}




\begin{tabular}{|c|c|c|c|c|c|}
\hline Time to Market (TTM) & 0.789 & 0.073 & 12.761 & 0.000 & 0.716 \\
\hline Time to Market (TTM) & 0.859 & 0.078 & 14.856 & 0.000 & 0.772 \\
\hline Time to Market (TTM) & 1.000 & & & 0.000 & 0.807 \\
\hline Product Innovation $(\mathrm{PI})$ & 0.888 & 0.077 & 17.599 & 0.000 & 0.854 \\
\hline Product Innovation (PI) & 0.934 & 0.084 & 21.016 & 0.000 & 0.924 \\
\hline Product Innovation (PI) & 1.000 & & & 0.000 & 0.967 \\
\hline
\end{tabular}

\section{Discussion and Managerial Implications}

The results concluded by our study include the following: The stakeholders' perceptions relating the initiatives of (CSR) of Saudi corporates, under study, have a positive effect on customer satisfaction, corporate reputation, and competitive advantage. The results have, on the one hand, illustrated that customer satisfaction plays mediating role in the relationship between (CSR) and competitive advantage. Corporate reputation also plays the same mediating role for the same relationship. The results also include that there is a positive relationship between customer satisfaction and corporate reputation. This means that customer satisfaction affects the competitive advantage in two ways. The first one has a direct impact of satisfaction on competitive advantage, and the second one has indirect impact through corporate reputation.

Based on the above mentioned, it has been demonstrated that the results of the analysis resulting from AMOS.16 program have confirmed all the hypotheses of this study. These results are significant because they help to clarify some of the ambiguity that surrounds the relationships of all variables used in the search, in particular, the impact of the initiatives of (CSR) in constructing a corporate competitive advantage and the nature of their relationship, which is proved as a positive relationship. The results also demonstrated that customer satisfaction and corporate reputation have an effect on constructing corporate competitive advantage. They also play a mediating role between the initiatives of social responsibility and competitive advantage. Analytical results of the study have demonstrated all those positive relationships. In conclusion, our study has demonstrated that social responsibility initiatives are affected and shaped by economic, legal, ethical, and discretionary activities of corporate. It has been demonstrated by the results of the study also said that customer satisfaction and corporate reputation play a mediating role between the initiatives of social responsibility and corporate competitive advantage. Customer satisfaction positively affects corporate reputation, which means that customer satisfaction has a vital role in constructing competitive advantage. Eventually, the analysis has demonstrated that constructing competitive advantage consists of five important factors, which are price/cost, quality, delivery dependability, product innovation, and time to market.

Consequently, the results of our study also demonstrate that Saudi corporates in general, and ones related with initiatives of social responsibility, especially, must seek to construct or maintain customer satisfaction because of its positive impact on corporate reputation on one hand, and on the competitive advantage on the other hand. Customer satisfaction, therefore, affects the competitive advantage; it also affects constructing a corporate positive reputation. Positive reputation interacts, at the same time, with customer satisfaction. According to Basdeo, Smith, \& Grimm (2006), corporate attempt to construct a good reputation or to enhance customer satisfaction leads to positive perceptions of stakeholders, and then gets a positive evaluation about the corporate. Consequently, it is said that participation in (CSR) forms positive inferences by stakeholders towards the corporate. It also helps the corporate to be subsequently advantageous to achieve the best reputation and to improve customer satisfaction. This actually leads, as the results of our study confirmed, to achieve a sustainable competitive advantage. Therefore, the benefits of (CSR) cannot be constrained by the intangible benefit. However, it can provide many benefits (Weber, 2008; Wood, 2010).

One of which is that corporates all over the world are facing a challenge to demonstrate responsible behavior of corporates before stakeholders. Nevertheless, providing evidences on the responsible behavior of corporates is not subject to opportunity cost. Executive managers also remain doubtful of engaging in (CSR) (McKinsey \& Company, 2006). The results of this study indicate that (CSR) appears as an effective strategic objective. Executives must consider (CSR) as a method to construct intangible assets such as customer satisfaction and corporate reputation. Both are one of the crucial objectives of most corporates. Both of them along with social responsibility initiatives have a strong active role in constructing sustainable competitive advantage. Therefore, corporates need to exert all their efforts to engage in the (CSR) activities, representing a powerful strategy, especially in a growing environment of social interests of the stakeholders. In fact, Porter and Kramer (2006) emphasized that the initiatives of (CSR) may be a new battlefield for competitive advantage. There is also another fact which is that the initiatives of CSR enhance customer satisfaction, corporate reputation, and 
competitive advantage. This, therefore, encourages these corporates to continue to invest in initiatives of corporate social responsibility. Customers tend to be more comfortable and satisfaction with corporates that are significantly socially responsible. They believe that these corporates are more positive in terms of corporate reputation, marketing spread, marketing share, and eventually achieving a sustainable competitive advantage.

\section{Conclusions, Limitations, and Future Researches}

Briefly, we believe that the variables studied in our research and the relationships among these variables, which have been tested in our model provide an explanation for how the initiatives of (CSR) have an effect on both consumer satisfaction and corporate reputation and on creating a sustainable competitive advantage. Consequently, the results of which we have concluded help to overcome some of the ambiguity that surrounds the relationship between the initiatives of (CSR) and competitive advantage. Our study could also provide insights for future researches from more realistic perspective. This study also emphasizes that engaging in the activity of (CSR) is likely to have positive benefits for corporates operating in Saudi Arabia. The current results indicated that the corporates involved in (CSR) appear to be able to enhance corporate reputation and to improve customer satisfaction, with a direct benefit from the initiatives of social responsibility, and indirect benefit through corporate reputation and customer satisfaction to create and improve competitive advantage.

Like many researches, there are restrictions on this study. Secondary sources, which have been a key structure in this study, are not adequately available for the appropriate sample size in Saudi Arabia. In the light secondary sources absence, and following the accepted practices, the survey method has been used to collect the data. Although this technology is not subject to restrictions, data collected from a single informant by using the survey method may be particularly susceptible to variation, and the desires of social bias. Spector and Brannick (1995) faced the desires of the social bias by using self-administered surveys, with a guarantee of anonymity for all participants. The survey questions have also been developed, and the dependent and independent variables have been separately maintained in the questionnaire.

It was confirmed by Nederhof (1985) that self-administered surveys restrict the desires of social bias from the rest of the other data collection methods because they reduce the emergence of social trends. In fact, studies concluded that the use of self-administered surveys have less effect by the desires of social bias more than those studies that rely on telephone or face-to-face personal interviews (Nederhof, 1984). Thus, while it is not always available the possibility of eliminating social bias desires, the evidences indicate that self-administered surveys using electronic surveys lead to less distortion than other methods (Nederhof, 1985).

The other matter here is that the research sample has been selected from the corporates operating in Saudi Arabia. Because we recognize that the results may not be generalized to other countries, the results provide empirical evidences of the possibility of the application or generalization in other countries. These countries may be the Gulf countries as they are the closest to the generalization, especially due to their involvement in many trends, cultures, and organizational methods adopted in Saudi Arabia. Among our research determinants, (CSR) has been portrayed and measured as problematic in the literature (Orlitzky, Siegel, \& Waldman, 2011; Van Oosterhout \& Heugens, 2008). Thus, we have provided an attempt to take advantage of widely recognized construction for corporate social responsibility, and we've tested it, which was provided by the Carrol's (1979). It has also been used in some other recent studies, including (Galbreath \& Shum, 2012). Therefore, using Carroll's (1979) study cannot be considered as a restriction itself. This is due to that we have tried to expand the range of tests of mediating role between the initiatives of social responsibility and competitive advantage. We did not aim at opening up new horizons in conceiving or measuring corporate social responsibility, but our primary goal was to expand the range of the standards previously used in the literature, which their credibility and reliability have sufficiently demonstrated.

\section{References}

Aaker, D. A., Kumar, V., \& Day, T. X. (2001). Marketing Research. New York: John Wiley and Sons.

Anderson, E. W., \& Sullivan, M. W. (1993). The antecedents and consequences of customer satisfaction for firms. Marketing Science, 12(2), 125-143. http://dx.doi.org/10.1287/mksc.12.2.125

Anderson, J. C., \& David, W. G. (1988). Structural Equation Modeling in Practice: A Review and Recommended Two-Step Approach. Psychological Bulletin, 103(May), 411-423. http://dx.doi.org/10.1037/00332909.103.3.411

Athanassopoulos, A. D. (2000). Customer satisfaction cues to support market segmentation and explain switching behavior. Journal of Business Research, 47, 191-207. http://dx.doi.org/10.1016/S0148-2963 (98)00060-5 
Bagozzi, R. P. (1992). The self-regulation of attitudes, intentions, and behavior. Social Psychology Quarterly, 55, 178-204. http://dx.doi.org/10.2307/2786945

Barnett, M. L., Jermier, J. M., \& Lafferty, B. A. (2006). Corporate Reputation: The Definitional Landscape. Corporate Reputation Review, 9(1), 26-38. http://dx.doi.org/10.1057/palgrave.crr.155001

Basdeo, D. K., Smith, K. G., \& Grimm, C. M. (2006). The impact of market actions on firm reputation. Strategic Management Journal, 27, 1205-1219. http://dx.doi.org/10.1002/smj.556

Basu, K., \& Palazzo, G. (2008). Corporate social responsibility: A process model of sense making. Academy of Management Review, 33(1), 122-136. http://dx.doi.org/10.5465/AMR.2008.27745504

Bhattacharya, C. B., \& Sen, S. (2003). Consumer-company identification: A framework for understanding consumers' relationships with companies. Journal of Marketing, 67(2), 76-88. http://dx.doi.org/10.1509/jmkg.67.2.76.18609

Bhattacharya, C. B., \& Sen, S. (2004). Doing better at doing good: When, why, and how consumers respond to social initiatives. California Management Review, 47(1), 9-24. http://dx.doi.org/10.2307/41166284

Bontis, N., Booker, L. D., \& Serenko, A. (2007). The mediating effect of organizational reputation on customer loyalty and service recommendation in the banking industry. Management Decision, 45(9), 1426-1445. http://dx.doi.org/10.1108/00251740710828681

Brady, M. K., \& Robertson, C. J. (2001). Searching for a consensus on the antecedent role of service quality and satisfaction: An exploratory cross-national study. Journal of Business Research, 51, 53-60. http://dx.doi.org/10.1016/S0148-2963 (99)00041-7

Brammer, S., \& Pavelin, S. (2004). Building a good reputation. European Management Journal, 22, 704-713. http://dx.doi.org/10.1016/j.emj.2004.09.033

Brammer, S., \& Pavelin, S. (2006). Corporate reputation and social performance: The importance of fit. Journal of Management Studies, 43, 435-455. http://dx.doi.org/10.1111/j.1467-6486.2006.00597.x

Brickley, J., Smith, C., \& Zimmerman, J. (2002). Business ethics and organizational architecture. Journal of Banking \& Finance, 26, 1821-1835. http://dx.doi.org/10.1016/S0378-4266 (02)00193-0

Brown, T. J., \& Logsdon, J. M. (1999). Corporate reputation and organization identity as constructs for business and society research. In Wood, D. J., \& Windsor, D. (Eds.), IABS proceedings (Tenth annual conference) (pp. 168-173). Paris: International Association for Business and Society.

Byrne, B. M. (2001). Structural equation modeling with AMOS: Basic concepts, applications, and programming. Mahwah, NJ: Lawrence Erlbaum Associates, Inc.

Carlisle, Y. M., \& Faulkner, D. (2005). The strategy of reputation. Strategic Change, 8(14).

Carroll, A. B. (1979). A three-dimensional conceptual model of corporate performance. Academy of Management Review, 4, 497-505.

Caves, R. E., \& Porter, M. E. (1997). From Entry Barriers to Mobility Barriers: Conjectural Decisions and Contrived Deterrence to New Competition. The Quarterly Journal of Economics, 91(2), 241-262. http://dx.doi.org/10.2307/1885416

Chand, M., \& Fraser, S. (2006). The Relationship between Corporate Social Performance and Corporate Financial Performance: Industry Type as a Boundary Condition. The Business Review, 5(1), 240-245.

Cochran, P. L., \& Wood, R. A. (1984). Corporate social responsibility and financial performance. Academy of Management Journal, 27(1), 42-56. http://dx.doi.org/10.2307/255956

Cronin, J. J. Jr., Brady, M. K., \& Hult, G. T. (2000). Accessing the effects of quality, value and customer satisfaction on consumer behavior intentions in service environments. Journal of Retailing, 76(2), 193-218. http://dx.doi.org/10.1016/S0022-4359 (00)00028-2

Donio, J., Massari, P., \& Passinate, G. (2006). Customer satisfaction and loyalty in a digital environment: An empirical test. Journal of Consumer Marketing, 23(7), 445-457. http://dx.doi.org/10.1108/07363760610712993

El-garaihy, W. H. (2013). Developing and Validating a Hospitality Service Quality Scale in Saudi Arabia (HOSP-SQ): A Structural Equation Model. International Journal of Business and Social Science, 4(14), 224-238. 
Flanagan, D. J., \& O'Shaughnessy, K. C. (2005). The effect of layoffs on firm reputation. Journal of Management, 31, 445-463. http://dx.doi.org/10.1177/0149206304272186

Fombrun, C. J. (2005). The leadership challenge: Building resilient corporate reputations. In J. P. Doh and S. A. Stumpf (Eds.), Handbook on responsible leadership and governance in global business (pp. 54-68). Cheltenham: Edward Elgar.

Fombrun, C., \& Shanley, M. (1990). What's in a name? Reputation building and corporate strategy. Academy of Management Journal, 33, 233-258. http://dx.doi.org/10.2307/256324

Freeman, R. E. (1984). Strategic management: A stakeholder perspective. Englewood Cliffs, NJ: Prentice Hall.

Galbreath, J., \& Shum, P. (2012). Do Customer Satisfaction and reputation mediate the CSR-FP link? Evidence from Australia. Australian Journal of Management, 37(2) 211-229. http://dx.doi.org/10.1177/0312896211432941

Gardberg, N. A., \& Fombrun, C. J. (2006). Corporate citizenship: Creating intangible assets across institutional environments. Academy of Management Review, 31(2), 329-346. http://dx.doi.org/10.5465/AMR.2006.20208684

Gruca, T. S., \& Rego, L. L. (2005). Customer satisfaction, cash flow, and shareholder value. Journal of Marketing, 69, 115-130. http://dx.doi.org/10.1509/jmkg.69.3.115.66364

Gueterbok, R. (2004). Greenpeace campaign case study - Stop Esso. Journal of Consumer Behavior, 33, 265271. http://dx.doi.org/10.1002/cb.139

Hair, J. F. Jr., Anderson, R. E., Tatham, R. L., \& Black, W. C. (1998). Multivariate Data Analysis (5th ed.). Upper Saddle River, NJ: Prentice Hall.

Holweg, M. (2005). An Investigation into Supplier Responsiveness. International Journal of Logistics Management, 16(1), 96-119. http://dx.doi.org/10.1108/09574090510617376

Jayachandran, S. S., Sharma, P. K., \& Pushkala, R. (2005). The Role of Relational Information Processes and Technology Use in Customer Relationship Management. Journal of Marketing, 69(October), 177-92. http://dx.doi.org/10.1509/jmkg.2005.69.4.177

Juholin, E. (2004). For business or the good of all? A Finnish approach to corporate social responsibility. Corporate Governance, 4(3), 20-31. http://dx.doi.org/10.1108/14720700410547477

Kotler, P., \& Keller, K. L. (2006). Marketing Management (12th Ed.). New Jersey: Pearson Education.

Koufteros, X. A., Vonderembse, M. A., \& Doll, W. J. (2002). Examining the Competitive Capabilities of $\begin{array}{lllll}\text { Manufacturing Firms. } & \text { Structural } & \text { Equation }\end{array}$ http://dx.doi.org/10.1207/S15328007SEM0902_6

Koufteros, X. A., Vonderembse, M. A., \& Doll, W. J., (1997). Competitive Capabilities: Measurement and Relationships. Proceedings Decision Science Institute, 3, 1067-1068.

Lai, C. S., Chiu, C. J., Yang, C. F., \& Pai, D. C. (2010). The effects of corporate social responsibility on brand performance: The mediating effect of industrial brand equity and corporate reputation. Journal of Business Ethics, 95(3), 457-469. http://dx.doi.org/10.1007/s10551-010-0433-1

Lamb, W. Jr. (2004). Marketing. Thompson south Western.

Li, S., Ragu-Nathan, B., Ragu-Nathan, T., \& Rao, S. S. (2006). The Impact of Supply Chain Management Practices on Competitive Advantage and Organizational Performance. Omega, 34(2), 107-124. http://dx.doi.org/10.1016/j.omega.2004.08.002

Lichtenstein, D. R., Drumwright, M. E., \& Braig, B. M. (2004). The effect of corporate social responsibility on customer donations to corporate-supported nonprofits. Journal of Marketing, 68(4), 16-32. http://dx.doi.org/10.1509/jmkg.68.4.16.42726

Luo, X., \& Bhattacharya, C. B. (2006). Corporate social responsibility, customer satisfaction, and market value. Journal of Marketing, 70, 1-18. http://dx.doi.org/10.1509/jmkg.70.4.1

Maignan, I., \& Ferrell, O. C. (2000). Measuring corporate citizenship in two countries: The case of the United States and France. Journal of Business Ethics, 23(3), 283-297. http://dx.doi.org/10.1023/A:1006262325211

Maignan, I., Ferrel, O. C., \& Hult, G. T. M. (1999). Corporate citizenship: Cultural antecedents and business benefits. Journal of the Academy of Marketing Science, 27(4), 455-469. 
http://dx.doi.org/10.1177/0092070399274005

Matten, D., \& Moon, J. (2004). Corporate Social Responsibility Education in Europe. Journal of Business Ethics, 54(4), 323-337.

McKinsey \& Company. (2006). Global survey of business executives. The McKinsey Quarterly, 1-10.

McWilliams, A., \& Siegel, D. (2001). Corporate social responsibility: A theory of the firm perspective. Academy of Management Review, 26(1), 117-127.

McWilliams, A., Siegel, D. S., \& Wright, P. M. (2006). Corporate social responsibility: Strategic implications. Journal of Management Studies, 43(1), 1-18. http://dx.doi.org/10.1111/j.1467-6486.2006.00580.x

Miles, M. P., \& Covin, J. C. (2000). A Source of Reputational, Competitive, and Financial Advantage. Journal of Business Ethics, 23(3), 299-311. http://dx.doi.org/10.1023/A:1006214509281

Mithas, S., Krishnan, M. S., \& Fornell, C. (2005). Effect of Information Technology Investments on Customer Satisfaction: Theory and Evidence. Working paper, Ross School of Business, University of Michigan.

Nederhof, A. J. (1984). Visibility of response as mediating factor in equity research. Journal of Social Psychology, 122, 211-215. http://dx.doi.org/10.1080/00224545.1984.9713482

Nederhof, A. J. (1985). Methods of coping with social desirability bias: A review. European Journal of Social Psychology, 15, 263-280. http://dx.doi.org/10.1002/ejsp.2420150303

Nunnally, J. C. (1978). Psychometric Theory (2nd ed.). New York: McGraw-Hill.

Oliver, R. L. (1997). Satisfaction: A behavioral perspective on the consumer. New York: McGraw-Hill.

Oliver, R. L., \& Swan, J. E. (1989). Consumer perceptions of interpersonal equity and satisfaction in transactions: A field survey approach. Journal of Marketing, 53, 21-35. http://dx.doi.org/10.2307/1251411

Orlitzky, M., Siegel, D. S., \& Waldman, D. A. (2011). Strategic corporate social responsibility and environmental sustainability. Business \& Society, 50, 6-27. http://dx.doi.org/10.1177/0007650310394323

Petrick, J. F. (2002). Development of a multi-dimensional scale for measuring the perceived value of a service. Journal of Leisure Research, 34(2), 119-134.

Ping, R. A. Jr. (1993). The effects of satisfaction and structural constraints on retailer exiting, voice, loyalty, $\begin{array}{llll}\text { opportunism, and } \text { neglect. Journal of } & \text { Retailing, }\end{array}$ http://dx.doi.org/10.1016/0022-4359(93)90010-G

Porter, M. E. (1985). Competitive Advantage: Creating and Sustaining Superior Performance. New York: Free Press.

Porter, M. E., \& Kramer, M. R. (2006). Strategy and society: The link between competitive advantage and corporate social responsibility. Harvard Business Review, 84, 78-92.

Powell, T. C. (2001). Competitive advantage: logical and philosophical considerations. Strategic Management Journal, 22(9), 875-888. http://dx.doi.org/10.1002/smj.173

Rowley, T., \& Berman, S. (2000). A brand new brand of corporate social performance. Business \& Society, 39, 397-418. http://dx.doi.org/10.1177/000765030003900404

Rust, R. T., \& Oliver, R. L. (1994). Service quality: Insights and managerial implications from the frontier. In T. R. Roland \& R. L. Oliver (Eds.), Service quality: New directions in theory and practice (pp. 1-19). New York: Sage Publications, Inc. http://dx.doi.org/10.4135/9781452229102.n1

Saeed, M., \& Arshad, F. (2012). Corporate social responsibility as a source of competitive advantage: The mediating role of social capital and reputational capital. Database Marketing \& Customer Strategy Management, 19(4), 219-232. http://dx.doi.org/10.1057/dbm.2012.19

Schnietz, K. E., \& Epstein, M. J. (2005). Exploring the financial value of a reputation for corporate social responsibility during a crisis. Corporate Reputation Review, 7(4), 327-345. http://dx.doi.org/10.1057/palgrave.crr.1540230

Schwaiger, M. (2004). Components and Parameters of Corporate Reputation-an Empirical Study. Schmalenbach Business Review, 56, 46-71.

Sen, S., \& Bhattacharya, C. B. (2001). Does Doing Good Always Lead to Doing Better? Consumer Reactions to Corporate Social Responsibility. Journal of Marketing Research, 38(May), 225-44. http://dx.doi.org/10.1509/jmkr.38.2.225.18838 
Smith, C. N. (2003). Corporate social responsibility: Whether or how? California Management Review, 45(4), 52-76. http://dx.doi.org/10.2307/41166188

Spector, P. E., \& Brannick, M. T. (1995). The nature and effects of method variance in organizational research. In Cooper, C. L., \& Robertson, I. T. (Eds.), International Review of Industrial Organizational Psychology (pp. 249-274). Chichester: John Wiley.

Spence, M. (2002). Signaling in retrospect and the informational structure of markets. American Economic Review, 92, 434-459. http://dx.doi.org/10.1257/00028280260136200

Stutz, F. P., \& Warf, B. (2009). The World Economy. Prentice Hall.

Sweeney, J. C., Soutar, G. N., \& Johnson, L. W. (2001). Consumer perceived value: Development of a multiple item scale. Journal of Retailing, 77(2), 203-220. http://dx.doi.org/10.1016/S0022-4359 (01)00041-0

Tracey, M., Vonderembse, M. A., \& Lim, J. S. (1999). Manufacturing Technology and Strategy Formulation: Keys to Enhancing Competitiveness and improving performance. Journal of Operations Management, 17(4), 411-428. http://dx.doi.org/10.1016/S0272-6963 (98)00045-X

Van Oosterhout, J., \& Heugens, P. (2008). Much ado about nothing: A conceptual critique of corporate social responsibility. In Crace A, McWilliams A, Wood, D. J. (Eds.), Measuring corporate social performance: A review.

Vickery, S. K., Calantone, R., \& Dröge, C. (1999).Supply Chain Flexibility: An Empirical Study. Journal of Supply Chain Management, 35(3), 16-24. http://dx.doi.org/10.1111/j.1745-493X.1999.tb00058.x

Walsh, G., Mitchell, V. W., Jackson, P. R., \& Beatty, S. E. (2009). Examining the antecedents and consequences of corporate reputation: A customer perspective. British Journal of Management, 20, 187-203. http://dx.doi.org/10.1111/j.1467-8551.2007.00557.x

Wang, Y., Lo, H. P., \& Hui, Y. V. (2003). The antecedents of service quality and product quality and their influences on bank reputation: Evidence from the banking industry in China. Managing Service Quality, 13, 72-83. http://dx.doi.org/10.1108/09604520310456726

Weber, M. (2008). The business case for corporate social responsibility: A company-level measurement approach for CSR. European Management Journal, 26, 247-261. http://dx.doi.org/10.1016/j.emj.2008.01.006

Weiss, A. M., Anderson, E., \& MacInnis, D. J. (1999). Reputation management as a motivation for sales structure decisions. Journal of Marketing, 63, 74-89. http://dx.doi.org/10.2307/1251975

\section{Copyrights}

Copyright for this article is retained by the author(s), with first publication rights granted to the journal.

This is an open-access article distributed under the terms and conditions of the Creative Commons Attribution license (http://creativecommons.org/licenses/by/3.0/). 